\title{
The Impact of Social Media on Higher Education in Kosovo: The Student's Perspective
}

\section{Gonxhe Beqiri, PhD.Cand.}

gonxhe@gmail.com

\section{Doi:10.5901/ajis.2014.v3n2p155}

\section{Abstract}

With the increase in the number of internet users, the use of social media has grown over the past decade. More concretely the usage has progressively grown from personal to also formal aspects. University students are active users of social media for academic as well as for personal purposes. Social Media represents one of the most direct and effective tools for students to communicate and interact with the proper subjects. The purpose of this paper is to analyze the impact of social media platform (email, social networks, blogs, instant messaging, etc.) in higher education in Kosovo, from the perspective of a student. Especially, in relation to the services offered by this platform in educational institutions where they study. In this study both primary and secondary sources of data were included. The secondary data are provided through literature gathered from published research articles. To answer the research questions, the primary data was collected through a structured questionnaire, that was sent to students in both electronic and hard copy version. The students were recruited from several higher education institutions in Kosovo. The sample was chosen having in consideration the statistical rules of representation. Data analysis was enabled through applied software Adobe Acrobat e-Forms (Adobe Acrobat forms central) and statistical interpretation through Excel format. The outcomes of this study show that there is an increase of social media usage within the students of higher education in Kosovo. Social Media has an impact and is considered as an effective tool by students about study related activities (activities related to subjects, research, group activities, projects, internship, etc.) and positive influence when it comes to communication and interactivity among them. Although, still it is recommended that the institutions where they study should be more active in the social media platforms, especially through Email (44 \%), Facebook (37 \%) and Google + (13 $\%)$.

Keywords: internet, social, media, higher, education.

\section{Introduction}

Socia Media is a great avenue for education institutions to interact with actual students and potential ones. It presents a platform that is evolving of digital media, based on the concept of sharing and discussing information among online users of the social community .

"Social media started in the late $90 \mathrm{~s}$, but was mostly the pervew of technology enthusiastists until about 2005. Before that the tools were to difficult for most people to use and as they got easier, adoption accelerated " (Israel, Sh. 2009, p. 189).

Nowdays we can enter a social media site and share links, add comments and make other activities that the platform provides. Social media helps making connections with students and between them. Students can share links , answer questions from the instructor and even post questions and comments to a fellow student (Heiberger, G. \& Harper, R. 2008, p.8).

According to Global Digital Statistics (2014, p.5) from 7.1 billion people in the world, 35\% of them have access to the internet, while $26 \%$ of them are active users of social media platform for various reasons. Based on the same report (p.11) the number of users of some web-sites key to this platform by ranking are (as seen in the figure below) : Facebook with 1.184 M users, Google + with 300 M users, Twitter with $232 \mathrm{M}$ active users, etc. 
Fig. 1. Active users by social platform

Source: Global digital statistics (wearesocial.sg)

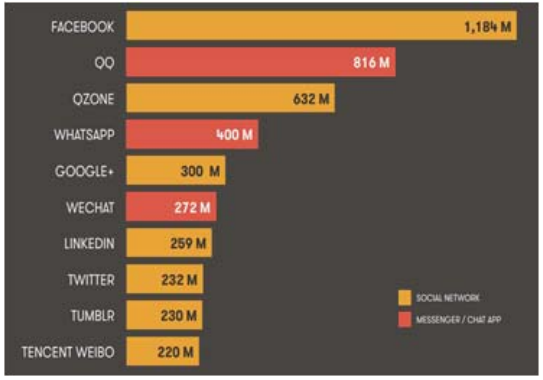

According to a report of Statistic Brain (2014, Social Networking Statistics) is worth mentioning that the usage of social media by age 18-29 years has reached a level of $90 \%$. Which represent a key indicator related to the usage of this platform from avarage age of the students.

\section{Literature Review}

Social media is all about getting connected to one another. Users of social media are connecting to each other regardless of national boundaries, culture or religion within fields and across industries (Ranjha, A . 2010, p.9). "Social Media strongly supports the logic to keep both students and the institutions updated with the evolving needs and offerings, by allowing them to have a more direct and social level of relation". (p.14.) .

Technology in today's society allows various ways for students to stay informed and aware of offerings at their universities. According to a annual survey of Social Media Use by Higher Education Faculty done by Perason Learning Solution (2013) the use of Social Media in teaching has grown 21,3\% from 2012 (34 \%) to 2013 (41\%). The same source idicates that the interactive nature of online and mobile technologies create better learning environments and that digital communication has increased communication with students.

According to Bayne, K. S. (2011, p.19) students are active on the social media platforms Facebook and Twitter and have the ability to obtain pertinent information about their campus centers. Another study analized by Davis.Ch.H.F, et.al. $(2012$, p.9.) based on a 456 U.S. educational institutions shows that the use of social media is increasing, $100 \%$ showing that they use at least some form of social media, especially leading the usage of Facebook (98\%) and Twitter (84 \%). Another study conducted in The Whittemore School of Business and Economics at the University of New Hampshire (UNH) showed that more students use Facebook and YouTube than any other social media platform. Blogs, Twitter, MySpace, and Linkedln had significantly lower amounts of student users.

Recent studies are showing that even professors are using social networking sites to assist in negotiating the teacher-student relationships. Yet, at many colleges and universities, administrators and faculty still wonder whether they should embrace $\mathbf{S N S}^{1}$ as a pedagogical tool (Harris.K, 2008) .

Table 1. Types of social media higher education institutions use (comparation between 2008-2011)

\begin{tabular}{|c|c|c|c|}
\hline Types of Social Media & $\mathbf{2 0 1 2 - 2 0 1 3}$ & $\mathbf{2 0 1 1 - 2 0 1 2}$ & $\mathbf{2 0 1 0 - 2 0 1 1}$ \\
\hline Facebook & $98 \%$ & $87 \%$ & $61 \%$ \\
\hline Twitter & $84 \%$ & $59 \%$ & $0.10 \%$ \\
\hline Blogging & $47 \%$ & $46 \%$ & $48 \%$ \\
\hline LinkedIn & $47 \%$ & $16 \%$ & $0 \%$ \\
\hline Message Boards & $37 \%$ & $38 \%$ & $36 \%$ \\
\hline
\end{tabular}

Source: Mashable (http://mashable.com/2012/02/03/higher-education-social-media/)

${ }^{1}$ Social Networking Service or Social Networking Site is a platform to build social networks or social relations among people who, share interests, activities, backgrounds or real-life connections. A website with multiple users where a user can publish content. The list includes Facebook, Google+, YouTube, Linkedln, Instagram, Pinterest, Tumblr and Twitter and other. http://en.wikipedia.org/wiki/Social _networking_service\#cite_note-2 
Social media is not a panacea for international student recruitment, and it comes with its own set of limitations and challenges. (Choudaha, R. 2013, pg. 10). Despite these limitations, social media is one of the biggest changes in terms of communication styles and engagement with prospective students.

Many educational institutions around the world already are operating through social media (social networks, blogs, email, etc.) contributing in development of student support service and having easier access to potential students . For example, in US according to Student Adviser ${ }^{2}$ (2012) John Hopkins University is ranked as \#1 among 100 other education institutions based on social media activity, following with Harvard University (\#2), University of Notre Dame (\#3) , Ohio State University (\#4) and Columbia University in the City of New York (\#5) . Te ranking was used by calculating Facebook Likes, Twitter Followers and YouTube subscribers The UK's Ivy League dominates the list with Oxford and Cambridge coming out on top.

Fig. 2 . Top Social Media Colleges in USA (2012) and UK (2013)
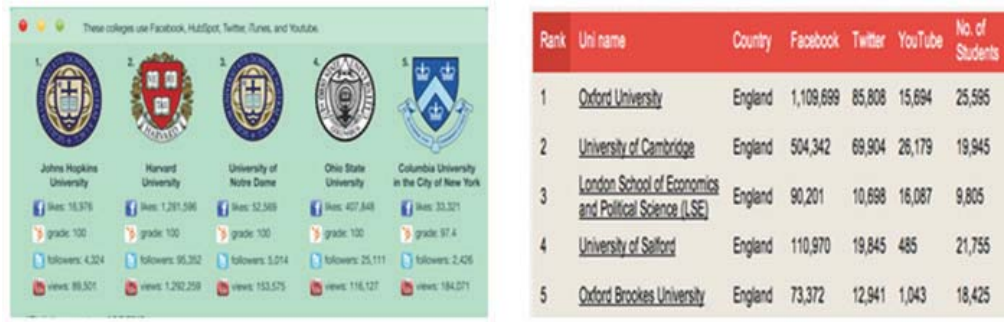

Sources: Student Advisor, Mashable and Theunipod: (http://geniusrecruiter.com/2013/10/31/top-social-mediauniversities-2013/)

"With social media , communication channels have converged and students are moving to quick services that are visually appealing and easy to use. As students use their smart phones more, they are also shifting in their use of social media". (Campus Quad Blog , Feb 19 2014).

\section{The Aim and Objectives of the Study}

The aim of this paper is to explain the current state of social media use from the perspective of students, in relation to the services offered by this platform in educational institutions where they study.

The main objectives of the paper are:

1. To understand the current usage of the social media by students, especially the specific web pages such as: email, social networks, blogs, instant messaging, etc.

2. To give a general view about the impact and effectiveness of using and adapting social media techniques to interact, get informed, increase the interest of the students about the activities and offers provided by higher educational institutions in Kosovo.

\section{Research Questions and Methodology}

The paper is oriented to elaborate on how much influence has the usage of social media by students (of higher education in Kosovo) for engaging in activities about their studies. In specific, the main research questions for this study are:

RQ1: To what use do students of higher education in Kosovo engage in social media study related activities, through E-mail, Facebook, Linkedln, Twitter and other social media web types?

RQ2: Does Social Media platform have an impact on increasing efficiency and interactivity among the students and the institutions where they study?

2"Student Advisor is a US-based college discovery site owned by The Washington Post Company. On this site students can research colleges with free match and compare tools and browse college reviews written by students and alumni (StudentAdvisor.com)". Powell,A. (December 6, 2010). "Compare College Rankings and Campuses with StudentAdvisor's One-Stop-Shop". BostInno. 
The study used a purposive sampling method to ensure a good representation of the target group that is higher education students as users of the social media networking sites.

Participants were recruited from several higher education institutions in Kosovo. The sample was chosen having in consideration the statistical rules of representation.

According to Kosovo Accreditation Agency (SER, 24 October 2013.p.9) the number of private higher education institutions in Kosovo is $25(89 \%)$ and the number of the public higher education institutions is $3(11 \%)$. The sample was taken for $56 \%$ of the private higher education institutions and $44 \%$ from the complete number of the general public institutions.

The methodology of this paper was based on data gathering through structured questionnaire. The questionnaire was formulated from group of questions, which aim on answering the two main research questions of this study. The questionnaire was designed by creating questions with only one possible answer, ranking questions, as well questions based on the Likert scale.

Students (from several private and public) institutions of higher education were requested to complete questionnaire an anonymous form, regarding the use of social media for their studies.

\section{Data Analysis and Interpretation}

In this study both primary and secondary sources of data were included. The secondary data are provided through a literature, gathered from published research articles review related to the study.

To collect the primary data, a questionnaire was built in both electronic and hard copy version. Questions in letter (traditional form) were transferred to electronic format through applied software Adobe Acrobat e-Forms (Adobe Acrobat forms central) and then were send to the participants (in this case the students) through e-mail or Web Acrobat Professional. The program Adobe Acrobat e-Forms enables automatic data processing and transfer, by downloading the spreadsheet, frequency tables for interpretation and statistical analyses in Excel format.

\section{The Participants}

To complete the procedure the $280(n=280)$ responded to the specific questions in the questionnaire. The gender demographics showed the following results: female (59\%) and male (41\%); $n=0$ undeclared (0\%). In terms of age, a majority of the respondents were 18-24 years old (66 \%), 25-35 (23\%), 35-44 (7\%) and 44 - more (4 \%).

The participant was asked to declare their employment status, which is an important indicator to show the amount of time that students can dedicate to their study engagement. This category was dominated with unemployed participants leading with $n=186(69 \%)$, full time employees (22\%) and part time employees (8 \%) with (1\%) undeclared.

In terms of university studies, graduate had the highest representation (at $76 \%$ ), followed by Post - Graduate studies (22\%) and $n=5$ undeclared (2\%).

The questionnaires were sent to students of different departments/ programs of the Universities. Dominating with their participation were those from department of Economy (29\%), following with Information Technology (14\%), Education (14\%), General Law (11\%), Art (8\%), Medicine (7\%) and the rest of the percentage represents students from other fields of studies offered by institutions of higher education in Kosovo.

Table 2. General information about the participants involved in this study (who responded the questions)

\begin{tabular}{|lcc|}
\hline Gender & $\mathrm{n}$ & $\%$ \\
\hline Female & 162 & 59 \\
Male & 114 & 41 \\
\hline Age & $\mathrm{n}$ & $\%$ \\
\hline $18-24$ & 182 & 66 \\
$25-34$ & 63 & 23 \\
$35-44$ & 20 & 7 \\
44 -more & 11 & 4 \\
\hline Employment status & $\mathrm{n}$ & $\%$ \\
\hline Full time employed & 59 & 22 \\
Part time employed & 23 & 8 \\
Unemployed & 186 & 69 \\
Other & 2 & 1 \\
\hline & & \\
\hline
\end{tabular}




\begin{tabular}{|lcc|} 
Current formal education & $\mathrm{n}$ & $\%$ \\
\hline Graduate & 203 & 76 \\
Post graduate & 59 & 22 \\
Other & 5 & 2 \\
\hline Study department & $\mathrm{n}$ & $\%$ \\
\hline Economy & $\mathbf{8 0}$ & 29 \\
IT & 40 & 14 \\
General Law & 31 & 11 \\
Medicine & 20 & 7 \\
Education & 38 & 14 \\
Art & 28 & 10 \\
Social Science & 21 & 8 \\
Other & 22 & 8 \\
\hline
\end{tabular}

\section{Social Media Usage by Students}

To answer research question \#1, precisely to understand the current situation of what extent do students of higher education in Kosovo engage in Social Media platform, $98 \%$ of the participants were frequent users of Internet, where 42 $\%$ of them searching for information's in Internet more than five times a day, following with $30 \%$ less than 5 times a day, $21 \%$ few times in a week and $5 \%$ few times in a month.

Student's engagement in internet is also attached to the amount of time they spend searching for information's about their studies with (62\%) spending less than 10 hours per week, (32\%) spend average 10-20 hours and (6\%) more than 20 hours per week. Some of them (53\%) connect to the internet and access social media platform through PC/Laptop, (33 \%) through Smartphone's and (3\%) from other devices.

There are many arguments weather Social Media is clearly understood among people; sometimes they can't distinguish social media from social news or other platforms. "It is easy to confuse social media with social news because we often refer to members of the news as "the media." (Nations, D. 2014). To understand if this is the case with the students that participated in this study, they were asked to answer if the term social media is familiar to them and do they use social media to get informed about their study subjects. The result were surprising, because almost all of them (96 \%) and (91\%) gave a positive response.

Facebook emerged as the favorite site (in terms of usage and popularity) for students (62\%) among other eight sites, Google + (31 \%) while Linkedln, Flickr and Twitter were the least favorite.

For those who currently have accounts in different social media web pages, they spend varying amounts of time on these sites. The most time spent by a preponderance of the students on all eight sites was about more than five hours per day. However, in terms of getting information about issues related to their studies social media doesn't represent the main channel, students

(93\%) also use other channels and sources. If social media is used properly by education institutions, it can provide them with insights into student activity and be effective as a retention tool. Students (64 \%) consider that the most important information's about their studies published in social media by their universities/colleges are the course related ones, following with (30\%) information about potential employment after graduation and (7\%) information about administrative issues.

Based in many sources and literature reviewed until now, interactivity ${ }^{3}$ is considered one of the most important indicators of communication among users through social media. In terms of students' interactivity, social media resulted to have a big impact with (92\%) considering that through social media they can communicate with other students and also see their progress after graduation.

Even that the students are interested to use social media for different reasons, they $(n=125)$ do not agree with the idea (52\%) to get information's about study related activities only through the mentioned platform. They suggest that the institutions where they study should provide more information's and be more active through Email (44\%), Facebook (37 $\%)$ and Google + (13\%). Giving a low importance (1\%) institutions activity through Twitter, Linkedln, Instagram and different Blogs.

${ }^{3}$ There are many definitions from different authors about the term Interactivity, however it becomes apparent that different media can display different levels of interactivity. Hoffman and Novak (1996) declare that: "Person interactivity is between humans through a medium and machine interactivity is between human and machine to access hypermedia content" (http://www.cerog.org/lalondeCB/CB/1999_lalonde_seminar/fortin.pdf) . 
To conclude the results and give a general view (in the graph below) about the research question \#1, students through the questionnaire (based on Likert-type declarative statement questions) were asked to give their opinion about some statements related to the importance of using social media in relation to their studies and interactivity with other students, professors, institutions representatives, etc.

Fig. 3. Frequency of the impact by Social Media usage among students

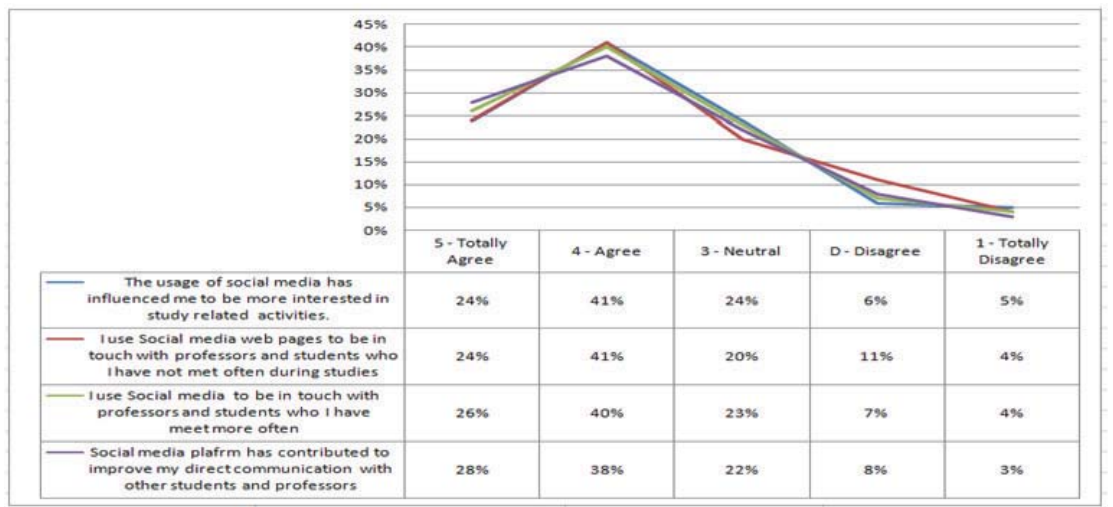

The results show that social media usage has contributed for the students to improve their direct communication , with (28 \%) strongly agreeing , (41\%) agree that social media has had an impact on them to be more interested about study related activities (activities related to subjects, research, group activities, projects, internship , etc.).

Social media has had a positive influence when it comes to communication among students and also among students and professors (40\% with those who they have not direct communication and $41 \%$ with those who they meet often).

There are several reasons why students use social media platform based in personal and formal level (as seen in the table nr.3).

Table.3. Usage of specific social media tools by students for formal and personal level

\begin{tabular}{|l|r|r|r|}
\hline & A- course-related activities & B-personal or other activities & C-Interaction with other students \\
\hline Email & $62 \%$ & $21 \%$ & $17 \%$ \\
\hline Instant Messaging (MSN, ICQ, Gtalk) & $17 \%$ & $64 \%$ & $20 \%$ \\
\hline Cell phone text messaging (SMS) & $12 \%$ & $76 \%$ & $12 \%$ \\
\hline Skype & $14 \%$ & $74 \%$ & $12 \%$ \\
\hline CMS (e- learning) & $52 \%$ & $26 \%$ & $22 \%$ \\
\hline Discussion forums & $21 \%$ & $21 \%$ & $57 \%$ \\
\hline Google Wave & $31 \%$ & $39 \%$ & $30 \%$ \\
\hline Blogs (Blogger, WordPress, ...) & $36 \%$ & $34 \%$ & $30 \%$ \\
\hline Wiki (MediaWiki, Pbwiki, Pmwiki, & $47 \%$ & $31 \%$ & $22 \%$ \\
\hline iTunes, Picasa, ...) & $21 \%$ & $61 \%$ & $18 \%$ \\
\hline Facebook & $26 \%$ & $55 \%$ & $19 \%$ \\
\hline Twitter & $13 \%$ & $69 \%$ & $18 \%$ \\
\hline Nexopia & $17 \%$ & $60 \%$ & $24 \%$ \\
\hline Other social networking site & $21 \%$ & $54 \%$ & $24 \%$ \\
\hline Ning & $13 \%$ & $61 \%$ & $26 \%$ \\
\hline Linkedln & $21 \%$ & $55 \%$ & $24 \%$ \\
\hline Other professional networking site & $26 \%$ & $48 \%$ & $25 \%$ \\
\hline Second Life (Bota virtuale) & $22 \%$ & $58 \%$ & $20 \%$ \\
\hline IMVU & $28 \%$ & $52 \%$ & $20 \%$ \\
\hline Other virtual world & $26 \%$ & $54 \%$ & $20 \%$ \\
\hline
\end{tabular}

Students are most likely to use email (62\%), a course management system (e-learning) (52\%) and Wikis (54 \%) for formal instructional activities and communication. By contrast, they use email (21\%) , a course management system (elearning) (26\%) and Wikis (31 \%) for informal communication and activities. In mentioned aspect they mostly like to cell phone text messaging, Skype, instant messaging, media sharing and Facebook (use ranging $60-76 \%$ ).

Forums are considered the favorite for students interactivity (group communication, group projects, etc.) leading with $(57 \%)$. 
To answer research question \#2, more concretely to understand if Social Media platform has an impact of increasing efficiency and interactivity among students of higher education and the institutions where they study, we got the following results.

In terms of of effectiveness of social media for course based information's, email is considered (62\%) extremely effective, following with Course Management System (54 \%). When it comes to Virtual World, they were essentially neutral $(n=102)$ and consider it the least effective (17\%). While the students consider email as most effective for their study related activities, in contrast for communication among them the most effective $(69 \%)$ are considered Social Networking Sites (such as Facebook, Twitter, etc.) , followed by email (59 \%) and Synchronous communication channels $(56 \%)$.

Table 4. Comparison of effectiveness by social media platform for course based information and communication among students ${ }^{4}$

\begin{tabular}{|c|c|c|c|c|c|c|c|c|c|c|}
\hline \multirow[t]{2}{*}{ Social Media } & \multicolumn{5}{|c|}{ Effectiveness for course based information } & \multicolumn{5}{|c|}{ Effectiveness for communication among student } \\
\hline & 1 & 2 & 3 & 4 & 5 & 1 & 2 & 3 & 4 & 5 \\
\hline Email & $62 \%$ & $29 \%$ & $6 \%$ & $1 \%$ & $1 \%$ & $59 \%$ & $29 \%$ & $5 \%$ & $4 \%$ & $3 \%$ \\
\hline $\begin{array}{l}\text { Synchronous communication } \\
\text { channels }\end{array}$ & $37 \%$ & $44 \%$ & $11 \%$ & $5 \%$ & $2 \%$ & $56 \%$ & $33 \%$ & $5 \%$ & $4 \%$ & $2 \%$ \\
\hline $\begin{array}{l}\begin{array}{l}\text { Course Management System (e- } \\
\text { learning) }\end{array} \\
\end{array}$ & $54 \%$ & $28 \%$ & $15 \%$ & $1 \%$ & $1 \%$ & $31 \%$ & $24 \%$ & $32 \%$ & $9 \%$ & $4 \%$ \\
\hline $\begin{array}{l}\text { Content Sharing Systems (e.g. } \\
\text { discussion, forums, wikis, blogs) }\end{array}$ & $45 \%$ & $26 \%$ & $22 \%$ & $4 \%$ & $3 \%$ & $34 \%$ & $40 \%$ & $15 \%$ & $10 \%$ & $2 \%$ \\
\hline $\begin{array}{l}\text { Social Networking Sites (Facebook, } \\
\text { Twitter) }\end{array}$ & $40 \%$ & $32 \%$ & $22 \%$ & $2 \%$ & $3 \%$ & $69 \%$ & $25 \%$ & $4 \%$ & $1 \%$ & $1 \%$ \\
\hline $\begin{array}{l}\text { Professional Networking Sites (e.g., } \\
\text { Ning, Linkedln) }\end{array}$ & $22 \%$ & $35 \%$ & $31 \%$ & $5 \%$ & $8 \%$ & $26 \%$ & $35 \%$ & $28 \%$ & $5 \%$ & $6 \%$ \\
\hline Virtual Worlds (e.g., Second Life) & $17 \%$ & $21 \%$ & $42 \%$ & $7 \%$ & $12 \%$ & $20 \%$ & $29 \%$ & $35 \%$ & $8 \%$ & $8 \%$ \\
\hline
\end{tabular}

To finalize the results, students were asked to show the satisfaction rate regard social media usage by the university where the study, in relation to marketing services and information's provided to them.

Fig 4. The level of satisfacion by students in relation to social media prformance of education institutions where they study

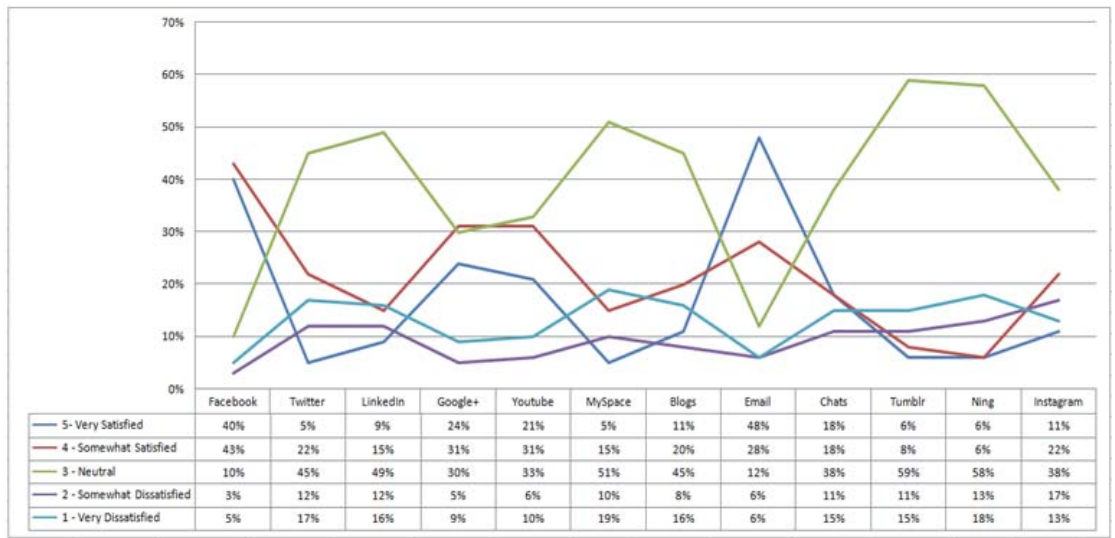

As seen in the graph (fig) nr.4, among twelve social media web pages, students consider email and Facebook as key indicators through which higher education is presented in the most proper way and from which they have access to information's, offers and communication in relation to higher education institutions were they study. Google + is also considered positive in a level. However, they are least satisfied with social media activities provided through Twitter, MySpace, Blogs and Instagram.

${ }^{4}$ In the table (nr.4), scale 1 - 5 represent student's answers based on selection : 1 - Very effective, 2- Effective, 3- Average, 4Ineffective and 5 - Very ineffective. The classification of the types of Social Media (seven in total) that the students had to choose is based by a research done in 2011 by Varnhagen, C. \& Husband,A. in University of Alberta about Social Media: Use and Usefulness. 


\section{Conclusion}

Even though that at first Social Media has been considered as an entertainment tool, because of it's priorities now it has been transformed into one of the key elements when it comes to efficiency, by offering advanced techniques and tools that every part of society can involve in different activities, such as formal and personal.

According to a report of Statistic Brain (2014, Social Networking Statistics), it says that the usage of social media is dominated by people of age 18-29 years old. When it comes to that fact it's worth mentioning that Kosovo is classified as one of the countries that have the youngest population in Europe.

Precisely, given the fact mentioned above, it was considered the main subject for the purpose of realization of this research. According to statistics conducted throughout this study is concluded that social media (based on the total number of participants who answered the questionnaire) are used (66 \%) by people of age 18-24 years old, (76\%) currently studying at the university level and (69\%) are unemployed.

From the perspective of social media web pages, Facebook emerged as the favorite site (in terms of usage and popularity) for students (62\%) among other eight sites, Google + (31 \%) while Linkedln, Flickr and Twitter were the least favorite. The most time spent by a preponderance of the students on all eight sites was about more than five hours per day.

Even that the students are interested to use social media for different reasons, they $(n=125)$ don't agree with the idea (52\%) to get information's about study related activities only through the mentioned platform.

In the terms of social media usage reasons, they consider email as a course management system (e-learning) (52 $\%$ ) and Wikis (54\%) for formal instructional activities and communication. By contrast, they use email (21\%) , a course management system (e-learning) (26\%) and Wikis (31 \%) for informal communication and activities. In mentioned aspect they mostly like to cell phone text messaging, Skype, instant messaging, media sharing and Facebook (use ranging 60 $76 \%)$.

Social Media is considered as a effective tool for course based information's, especially email is considered (62 \%) extremely effective, following with Course Management System (54 \%). While, for communication among them they consider as the most effective (69\%) the Social Networking Sites (such as Facebook, Twitter, etc.) , followed by Email (59 $\%)$ and Synchronous communication channels (56\%).

Students consider Email and Facebook as key indicators through which higher education is presented in the most proper manner (in terms of information access, offers and communication in relation to higher education institutions were they study). However is recommended, that the institutions where they study should be more active by social media platform and especially through Email (44 \%), Facebook (37 \%) and Google + (13\%).

The results show that Social Media has an impact on students about study related activities (activities related to subjects, research, group activities, projects, internship , etc.) and positive influence when it comes to communication and interactivity among them.

\section{References}

Bayne, Kendra S. (2011) "Effectiveness of Social Media Marketing: An Experimental Inquiry on College Students' Awareness of, Interest in, and Intention to Participate in a Campus Recreation Special Event". Kinesiology Theses. Paper 2. Retrieved from: http://scholarworks.gsu.edu/cgi/viewcontent.cgi?article=1001\&context=kin_health_theses

Charles, H.F. Davis III, et. al. (2012). Social Media in Higher Education: A literature review and research directions. The Center for the Study of Higher Education at The University of Arizona AND Claremont Graduate University. Retrived from: http://works.bepress.com/cgi/viewcontent.cgi?article=1003\&context=hfdavis

CampusQuad. (2014). The Evolution of Social Media Use Among College Students. Access date: 12.04.2014. Available at : http://www.campusquad.co/evolution-social-media-use-among college-students-2/

Choudaha, R. (2013). Social Media in International Student Recruitment. Association of International Education Administrators (AIEA) Issue Brief, March 2013. Retrived from: http://www.aieaworld.org/assets/docs/lssue_Briefs/social_media_recruitment_issue brief2013march.pdf

Fortin, R.D. \& Dholakia, R. R. (2003). Interactivity and vividness effects on social presence and involvement with a web-based advertisement. Journal of Business Research 58 (2005) 387 - 396. D 2003 Elsevier Inc. Retrived from: http://www.cerog.org/lalondeCB/CB/1999_lalonde_seminar/fortin.pdf

Global Digital Statistics . (2014). We are Social's Snapshot of Key Digital Indicators. Retrived from: http://etonpreneurs.com/uploads/Global\%20Social,\%20Digital\%20\&\%20Mobile\%20Statistics,\%20Jan\%202014.pdf

Genius Recruiter. (2013). Top Social Media Universities 2013. Access date : 27.04.2014. Available at: http://geniusrecruiter.com/2013/10/31/top-social-media-universities-2013/ 
HARRIS, K. (2008). Using Social Networking Sites as Student Engagement Tools. Diverse: Issues in Higher Education;10/16/2008, Vol. 25 Issue 18, p40. Retrived from: http://diverseeducation.com/article/11837/

Heiberger, G. \& Junco, R. (2011). Meet your students where they are: Social media. NEA Higher Education Advocate. Retrived from : http://www.nea.org/assets/docs/HE/1109Advocate_pg06-09.pdf

Israel, Sh. (2009). Twitterville: How Businesses Can Thrive in the New Global Neighborhoods. Portfolio Hardcover; First Printing edition.

Nations, D. (2014). What is Social Media? What are Social Media Sites? Access date: 02.05.2014. Available at : http://webtrends.about.com/

Powell, A. (2010). "Compare College Rankings and Campuses with StudentAdvisor's One-Stop-Shop". Bostlnno. Access date: 04.05.2014. Available at: http://bostinno.streetwise.co/2010/12/06/compare-college-rankings-and-campuses-withstudentadvisor\%E2\%80\%99s-one-stop-shop/

Raport i Vetë -Vlerësimit. (24 tetor, 2013). Agjencia e Kosovës përAkreditim (AKA). Retrived from: file:///D:/Users/hp/Downloads/AKA\%20RVV\%202014.pdf

Ranjha, A. (2010). Promoting Tourism in Abu Dhabi using Social Media. Royal Institute of Technology.School of Computer Science and Communication . KTH CSC.SE-100 44,

Stockholm, Sweden. Retrived from: http://www.nada.kth.se/utbildning/grukth/exjobb/rapportlistor/2010/rapporter10/ranjha_ahmed_10159.pdf

Seaman, J \& Kane, T. K. (2013). Social Media for Teaching and Learning. Pearson Learning Solutions and Babson Survey Research Group. Retrived from: http://www.pearsonlearningsolutions.com/assets/downloads/reports/social-media-for-teaching-andlearning-2013-report.pdf\#view=FitH,0 and http://www.edudemic.com/social-media-in-education/

Silverman, M . (2012). How Higher Education Uses Social Media [INFOGRAPHIC]. Mashable. Acces date: 02.05.2014. Available at: http://mashable.com/2012/02/03/higher-education-social-media/

Social Networking Statistics. (2014). Statistic Brain. Access date: 13.04.2014. Available at: http://www.statisticbrain.com/socialnetworking-statistics/

University of New Hampshire Research Team. (2009). Social networking usage and grades among college students. A Study to Determine the Correlation Of Social Media Usage and Grades. The Whittemore School of Business and Economics at the University of New Hampshire (UNH). Retrived from: http://www.unh.edu/news/docs/UNHsocialmedia.pdf

Varnhagen, C. \& Husband, A. (2011). Social Media: Use and Usefulness at the University of Alberta. Report of the TLAT Subcommittee on Social Media. Retrieved from: http://ctl.ualberta.ca/sites/default/files/files/Social\%20Media-\%20Use\%20and\%20Usefulness \%20at\%20the\%20University\%20of\%20Alberta-Report\%20of\%20TLAT\%20Subcommittee\%20on\%20Social\%20Media.pdf 
